\title{
Social Engineering Model of the Relationship between State Institutions and Federal Government of the Republic of Indonesia: From the Perspectives of the Indonesian 1945 Constitution
}

\author{
${ }^{1}$ Yusri Munaf, ${ }^{1}$ Rahyunir Rauf, ${ }^{2}$ Ellydar Chaidir, ${ }^{3}$ Zakir Has, ${ }^{4,6}$ Sharifah Zarina Syed Zakaria, \\ ${ }^{5}$ Kadir Arifin and ${ }^{6}$ Muhammad Rizal Razman \\ ${ }^{1}$ Faculty of Social and Political Studies (FISIPOL), \\ ${ }^{2}$ Faculty of Law, \\ ${ }^{3}$ Faculty of Economics, Universitas Islam Riau (UIR), Jalan Kaharuddin Nasution, \\ No. 113, Simpang Tiga Marpoyan, 28284 Pekanbaru, Riau, Indonesia \\ ${ }^{4}$ Research Centre for Environmental, Economic and Social Sustainability (KASES), \\ Institute for Environment and Development (LESTARI), \\ ${ }^{5}$ Social, Environmental, Developmental Sustainability Research Centre (SEEDS), \\ Faculty of Social Sciences and Humanities (FSSK), \\ ${ }^{6}$ Research Centre for Sustainability Science and Governance (SGK), \\ Institute for Environment and Development (LESTARI), Universiti Kebangsaan Malaysia, \\ 43600 UKM Bangi, Selangor, Malaysia
}

\begin{abstract}
In the life of the state in Indonesia in accordance with the provisions in the 1945 Constitution, Indonesia does not adhere to trias politic's teachings with the separation of powers. Inter-agency relationships are based on the principle of power-sharing contained in the 1945 Constitution. In the development of state institutions in Indonesia must be consistent in performing their functions amid the increasingly complex of modern state activities, the more institutions or equipment needed. Tools or institutions that are created through the constitution are often no longer able to accommodate specific tasks that generally, require independence and professionalism in the implementation. In the 1945 Constitution of the State of the Republic of Indonesia (the 1945 Constitution) before the amendment, there are six highest/highest state institutions, namely the People's Consultative Assembly as the highest state institution; as well as DPR, president, MA, BPK and DPA as state high institutions. However, after changing the 1945 Constitution (Amendment), it is stated that the state institution is affiliated with the MPR, DPR, DPD, president, BPK, MA, MK and KY without knowing the term of the highest or the highest state institution. This study tries to provide an overview of the implementing social engineering model in relationship between state institutions in Indonesia amid the complexity of state activities in Indonesia.
\end{abstract}

Key words: Social engineering, relationship, state institutions, Indonesian 1945 Constitution, implementation, professionalism

\section{INTRODUCTION}

State institutions arise from embodying the concept of tries political as a power-sharing representation. For example in Indonesia, the executive power is implemented in the form of a state institution called a presidential presidency presided over by a president; the legislative power is implemented in the form of a state party called the House of Representatives (DPR), judicial power is implemented in the form of a state institution called the Supreme Court (MA) and the Constitutional Court (MK).
The relationship between the state institutions will form a system of government. Bintan R. Saragih mentions the governance system as a whole of the orderly arrangement of state institutions relating to one another directly either directly or indirectly according to the plan or pattern to achieve the state's objectives (Ali et al., 2017; Chaidir, 2008; Emrizal and Razman 2010).

In the 1945 Constitution of the State of the Republic of Indonesia (the 1945 Constitution) before the amendment, there are six highest/highest state institutions, namely the People's Consultative Assembly

Corresponding Author: Yusri Munaf, Faculty of Social and Political Studies (FISIPOL), Universitas Islam Riau (UIR), Jalan Kaharuddin Nasution, No. 113, Simpang Tiga Marpoyan, 28284 Pekanbaru, Riau, Indonesia 
as the highest state institution; as well as DPR, president, MA, BPK and DPA as state high institutions. However, after changing the 1945 Constitution (Amendment), it is stated that the state institution is affiliated with the MPR, DPR, DPD, president, BPK, MA, MK and KY without knowing the term of the highest or the highest state institution. This study provides a brief overview of how the relationship between state institutions in Indonesia according to the 1945 Constitution.

\section{MATERIALS AND METHODS}

The terminology of state institutions: "Institution" includes an agency (organization) aimed at conducting a scientific investigation or undertaking a business and an established human behavior pattern consisting of structured structural interactions in a relevant value framework (Akbar, 2013; Khairil et al., 2017; Razman et al., $2009 \mathrm{a}-\mathrm{c})$.

Sociologically distinguished between institutions in the practice of life that has been run on an inheritance (institution) and institutions in the sense of the organization (institute). The state institution is a government institution or "civilization organization" where the institution is made by the state from the state and to the country where it aims to build the country itself. The meaning of the state institutions is the state instrument of means as intended by the 1945 Constitution (Akbar, 2013; Razman and Azlan, 2009; Razman et al., 2010).

Actually, simply, the term organ of a state or state institution can be distinguished from the words of a private organ or institution, a public institution or so-called $\mathrm{NGO}$ or Non-Governmental Organization in English called Non-Government Organization (NGO) or Non-Government Organizations). Therefore, any institution that is formed not as a community institution can be called as a state institution. The state institution can be in the legislative, judicial or mixed-up sphere (Asshiddiqie, 2006 and Razman, 2014, 2015).

In the view of Hans Kelsen whoever carries out a function established by the rule of law is an organ. This function, whether in the form of norms or practices is ultimately all directed to the implementation of legal sanctions. Parliaments establishing criminal law and citizens who vote for parliament are the organs of the state including judges who punish the criminals and individuals who actually carry out the sentence. According to this sense, the organ is an individual performing a particular function. The quality of a person as an organ is formed by its function. $\mathrm{He}$ is an organ because and as long as he performs the function of making or applying the law (Kelsen, 2007, Razman et al., 2014, 2015).

Just as humans have the equipment to move and work, even state organizations have the equipment. This tool of equipment realizes the goals and desires of the state (stats will). State tools can be termed in terms of organ, institution, forum, institution, state auxiliaries, independent state bodies or self-regulatory bodies, state enterprises and others (Kelsen, 2007).

The more complex the modern state activities, the more institutions or equipment needed. Tools or institutions that are created through the constitution are often no longer able to accommodate specific tasks that generally, require independence and professionalism in the implementation. Thus, the formation of equipment or organization (institution) is a new condition sine qua non for the growth of the country in this third-millennium era (Nurtjahjo, 2005). This theory of state equipment provides the basis for scrutiny of the further arrangement of state institutions present as new tools, especially for our reforming country.

Relations between MPR and DPR, DPD and constitutional court: In the 1945 Constitution, the MPR is one of the state institutions (before the Amendment is known by the term of the highest institution of the State). Members of the People's Consultative Assembly consisting of members of the DPR and DPD members indicate that the MPR is still viewed as a representative body of the people because of its membership elected in the general election. Elements of members of parliament to reflect the principles of political democracy while elements of DPD members to reflect the principle of regional representation, so that, regional interests are not neglected. With the change of position of the MPR, the understanding of the form of popular sovereignty is reflected in the three branches of power namely the representative institution, the president and the holder of judicial power (Akbar, 2013 and Chaidir, 2008).

The MPR's authority shall be to amend and enact the Constitution, elect the president and/or vice president in the event of a vacancy of the president and/or vice president, inaugurating the president and/or vice president and the authority to dismiss the president and or vice president according to the constitution (Akbar, 2013, Chaidir, 2008).

In relation to the People's Legislative Assembly, specifically regarding the holding of MPR sessions relating to the authority to dismiss the president and/or vice president, such process can only be done if it is preceded by the opinion of the People's Legislative 
Assembly submitted to the MPR. In conjunction with DPD. Like the role of the DPR, the DPD's role in the MPR is also very large for example in terms of changing the constitution which must be attended by $2 / 3$ MPR members and dismissing the president which must be attended by $3 / 4$ MPR members, the DPD's role in the authority is a must (Akbar, 2013, Chaidir, 2008).

In the case of its relationship with the Constitutional Court (MK) can be understood from Article 24C paragraph (1) of the 1945 Constitution states that one of the authorities of the constitutional court is to decide the dispute over the authority of state institutions whose authority is granted the Constitution. Because of the position of the MPR as a state institution, if the MPR disputes with other state institutions which have the same authority determined by the constitution, then the conflict must be resolved by the constitutional court.

Relations between the house and the president, DPD and MK: The House of Representatives consists of DPR and $\mathrm{DPD}$. The difference between the two lies in the nature of the interests it represents, the DPR to represent the people while the DPD to represent the regions. Article 20 paragraph (1) states that the DPR holds the power to form laws. Furthermore in order to strengthen the position of DPR as the holder of legislative power, Article 20 paragraph (5) stipulates that in the case of a jointly approved bill not approved by the president within 30 days of the approval, legislation becomes law and must be enacted.

In connection with the DPD, there is a working relationship in terms of participating in discussing the Bill related to a particular field, the DPD gives consideration to certain bill and conveys the results of supervision of the implementation of certain laws in the DPR. In relation with the constitutional court, there is a working relationship that is in terms of demand DPR to the constitutional court to examine the opinion of the House of Representatives regarding the allegation that the president was guilty. In addition, there are other working relationships such as in case of any dispute with other state institutions, the process of nominating candidates for constitutional justices and the process of submitting the opinion of the People's Legislative Assembly which states that the president is guilty of being questioned by the constitutional court (Nurtjahjo, 2005).

Relationship of DPD with DPR, BPK and MK: The duties and powers of the DPD relating to the DPR are in the case of proposing a specific bill to the parliament, participating in discussing specific bill with the parliament, giving consideration to the DPR over the certain bill and submitting the results of supervision on the implementation of certain laws in the DPR. In this regard, the DPD as a representative institution that represents the region in exercising its authority is by prioritizing regional interests.

In conjunction with $\mathrm{BPK}$, the $\mathrm{DPD}$ under the provisions of the constitution receives the results of the BPK audit and gives consideration to the election of members of BPK. This provision gives the DPD the right to make the results of BPK's financial statements as material in the context of carrying out its duties and authorities and to participate in determining the membership of BPK in the process of selecting members of BPK. In addition, the BPK report will be used as a material to submit proposals and considerations regarding the bill on state budget. In relation to the constitutional court, there is a working relationship relating to the authority of the constitutional court in case of any dispute with other state institutions (Nurtjahjo, 2005).

MA relationship with other state institutions: Article 24 paragraph (2) states that judicial power is exercised by a supreme court and its subordinate courts and by a constitutional court. The provision states the peak of judicial power and the rule of law is in the supreme court and the constitutional court. The supreme court is an independent institution and should be free from the influence of other branches of power. In conjunction with the constitutional court, the supreme court proposes 3 constitutional court judges to be appointed as judges in the constitutional court (Nurtjahjo, 2005).

The relationship between the constitutional court with the president, DPR, BPK, DPD, MA, KY: The authority of the constitutional court in accordance with the provisions of Article 24C paragraph (1) and (2) is to hear at the first and final level to examine the law against the constitution, to decide upon the dispute over the authority of state institutions whose authority is granted by the constitution, to decide upon the dissolution of political parties and to decide upon disputes concerning the results general election. In addition, the constitutional court is also obliged to provide a decision on the opinion of the House of Representatives regarding alleged violations by the president or vice president according to the constitution. With such authority, it is clear that the constitutional court has a working relationship with all state institutions, namely when there is a dispute between state institutions or in case of judicial review process submitted by state institutions to the constitutional court. 
The relationship between BPK with DPR and DPD: BPK is a free and independent institution to examine the management and responsibility of the state finances and the results of such examination shall be submitted to the DPR, DPD and DPRD. With the regulation of BPK in the constitution, there is a development that is related to structural changes in the form of the organization and the extension of the scope of functional examination tasks. Because the current BPK audit also on the implementation of the state budget in the regions and must submit the results in addition to the House of Representatives also in the DPD and DPRD. In addition to the state budget audit framework, the relationship between BPK and DPR and DPD is in the process of selecting members of BPK (Nurtjahjo, 2005).

The relationship between the judicial commission and the supreme court: Article 24A paragraph (3) and Article 24B paragraph (1) confirm that the supreme court nominee shall be proposed by the judicial commission to the parliament for approval. The existence of the judicial commission cannot be separated from the judiciary. From this provision that the position of judge is a position of honor that must be respected, guarded and upheld honor by an institution that is also independent. In conjunction with the supreme court, the task of KY is only related to the function of proposing the appointment of the supreme court justice while the appointment of appointment of other judges such as the constitutional court judges are not associated with $\mathrm{KY}$.

\section{RESULTS AND DISCUSSION}

Critical thinking: After the reformation period in 1998, there was a change in almost all sectors of life and one of the greatest was the existence of constitutional reform in the form of the 1945 Constitution amended in four changes. The changes are quite large both in terms of quantity and quality. In terms of quantity alone, it can be concluded that the 1945 Constitution, after four changes, experienced a massive change even though the name of the 1945 Constitution of the Republic of Indonesia was retained (Akbar, 2013 and Chaidir, 2008).

In terms of quality, changes can be seen from the paradigm of thought or thoughts contained in the formulation of the articles of the 1945 Constitution after experiencing the four times the change is completely different from the main ideas contained in the original text when the 1945 Constitution was first ratified on August 18,1945 . In fact, in Article II the supplementary rules of the fourth amendment of the 1945 Constitution are affirmed "with the amendment of this constitution, the
1945 Constitution of the State of the Republic of Indonesia consists of the opening and the articles". Thus, since, August 10, 2002, the status of explanation of the 1945 Constitution which has been used as an annex is inseparable from the text of the 1945 Constitution is no longer a part of the text of the constitution (Akbar, 2013 and Chaidir, 2008).

One of the fundamental changes during the fourth amendment of the 1945 Constitution is about the arrangement of relationships between existing state institutions where currently there is no longer the supreme state institution, there is only the state high institution which between one state institution with other state institutions run the system check and balances. Among the state's high institutions are president and vice president, DPR, MA and MK. Prior to the amendment of the 1945 Constitution, the institutional system adopted was not a separation of power but was often referred to as the distribution of power. The president not only holds the highest administrative power (executive) but also holds the power to form legislation or legislative powers together with the DPR as his co-legislator. while the question of judicial power (judiciary) in the 1945 Constitution before the amendment is done by an MA and other judicial bodies according to law. In addition, the 1945 Constitution of 1945 after the reform era and amendment with four changes has brought fresh air for the people of Indonesia because in it the recognition of human rights for the people of Indonesia is set stronger, detailed and become a very protected basic rights, even when there is a legislation that is suspected and proven to violate human rights, then the laws and regulations can be canceled and declared invalid, through the decision of the constitutional court (Akbar, 2013 and Chaidir, 2008).

\section{CONCLUSION}

A state institution is a central government institution whose functions, duties and authorities are strictly regulated in the constitution. Overall, the 1945 Constitution of the State of the Republic of Indonesia (UUD 1945) before the amendment recognizes the six highest and highest state institutions, namely: MPR as the highest state institution; DPR, president, MA, BPK and DPA as state high institutions. However, after the amendment, the 1945 Constitution states that state institutions are MPR, DPR, DPD, president, BPK, MA, $\mathrm{MK}$ and $\mathrm{KY}$ without knowing the term institution of high or the highest state. Reform in 1998, there was a change in almost all sectors of life and one of the greatest was the existence of constitutional reform in the form of the 1945 Constitution amended in four changes. 
In addition to the recognition of human rights, the 1945 Constitution also regulates how good and healthy state institutions are linked, no longer the highest state institutions that can indirectly regulate other state institutions. All become equal and equal to the principle of check and balances. This principle, making every state institution in carrying out its duties and authority will always involve other state institutions. So with these positions and principles, the likelihood of arbitrary actions from state institutions becomes small. This becomes important in accordance with Lord Acton's theory of "power tends to corrupt and absolute power corrupts absolutely". This means that power has the potential to generate arbitrariness (corrupt) when its power is absolute, then there will certainly be arbitrariness (corrupt).

\section{ACKNOWLEDGEMENT}

Part of this study was conducted by using funding from the research projects of the XX-2018-008.

\section{REFERENCES}

Akbar, P., 2013. [State Institutions According to the 1945 Constitution of the Republic of Indonesia]. Sinar Grafika, East Jakarta, Indonesia, ISBN:9789790075597, Pages: 247 (In Indonesian).

Ali, M.N., M.R. Razman, Z. Ramli and K. Arifin, 2017. Understanding aggressive behaviour to avoid damages through the precautionary principle towards the Sustainable Development Goals (SDGs). J. Food Agric. Environ., 15: 52-55.

Asshiddiqie, J., 2006. [Development and Consolidation of Post-Reform State Institutions]. Penerbit Sekretariat dan Kepaniteraan Mahkamah Konstitusi Republik Indonesia, Jakarta, Indonesia, ISBN: 9789799998927, Pages: 377 (In Indonesian).

Chaidir, E., 2008. [Government System of the Republic of Indonesia Post Amendment to the 1945 Constitution]. Total Media, Yogyakarta, Indonesia, Pages: 442 (In Indonesian).

Emrizal and M.R. Razman, 2010. The study on international environmental law and governance: Focusing on the montreal protocol and the role of transboundary liability principle. Soc. Sci., 5: 219-223.

Kelsen, H., 2007. [General Theory of Law and State (Translation by Somardi)]. Bee Media Indonesia, Jakarta, Indonesia,.

Khairil, M., M.R. Razman, Z. Ramli and K. Arifin, 2017. Understanding terrorism based on radicalism idea in order to avoid instability for achieving environmental peace and justice the Sustainable Development Goals (SDGs). J. Food Agric. Environ., 15: 48-51.
Nurtjahjo, H., 2005. [State Science: Development of State Theory and Supplements]. Rajawali Pers, Jakarta, Indonesia, ISBN:9789797690168, Pages: 204 (In Indonesian).

Razman, M.R. and A. Azlan, 2009. Safety issues related to Polychlorinated Dibenzo-p-Dioxins (PCDDs) and Polychlorinated Dibenzofurans ( $\mathrm{PCDFs}$ ) in fish and shellfish in relation with current Malaysian laws. J. Food Agric. Environ., 7: 134-138.

Razman, M.R., 2014. Sale of goods act, 1957: The role of statutory implied terms towards food and environmental sustainability. Res. J. Appl. Sci., 9: 624-628.

Razman, M.R., 2015. A study on global financial mechanisms in the montreal protocol from environmental law and management perspectives. Int. Bus. Manage., 9: 111-116.

Razman, M.R., A.S. Hadi, J.M. Jahi, A.H.H. Shah and A.F. Mohamed et al., 2009a. The international law mechanisms to protect human habitat and environment: Focusing on the principle of transboundary liability. Int. Bus. Manage., 3: 43-46.

Razman, M.R., A.S. Hadi, J.M. Jahi, A.H.H. Shah and S. Sani et al., 2009c. A study on negotiations of the montreal protocol: Focusing on global environmental governance specifically on global forum of the united nations environmental programme. J. Food Agric. Environ., 7: 832-836.

Razman, M.R., A.S. Hadi, J.M. Jahi, A.H.H. Shah and S. Sani et al., 2010. A study on the precautionary principle by using interest approach in the negotiations of the montreal protocol focusing on the international environmental governance and law. J. Food Agric. Environ., 8: 372-377.

Razman, M.R., A.S. Hadi, J.M. Jahi, K. Arifin and $\mathrm{K}$. Aiyub et al., 2009b. The legal approach on occupational safety, health and environmental management: Focusing on the law of private nuisance and International Labour Organisation (ILO) decent work agenda. Int. Bus. Manage., 3: 47-53.

Razman, M.R., M.B. Mokhtar, S.Z.S.Zakaria, K. Arifin and N.F.A. Bakar, 2014. The process of negotiations towards acceptance of the montreal protocol in Malaysia: Focusing on environmental management. Information (Japan), 17: 1255-1262.

Razman, M.R., N.H. Nordin, M.B. Mokhtar, S.Z.S. Zakaria and $\mathrm{K}$. Arifin et al., 2015. A study on packaged food safety in Kajang Municipal Council towards food and environmental sustainability. Information, 18: 521-536. 